\title{
The earliest public green areas connected with Jelenia Góra, part. 1.
}

\author{
Marzanna Jagiełło, Wojciech Brzezowski \\ Faculty of Architecture, Wroctaw University of Since and Technology
}

\begin{abstract}
Summary: In the third part of the $18^{\text {th }}$ century the earliest public landscape gardens began to appear in the area of suburban Jelenia Góra. They were the first public parks in Silesia. When establishing them, the natural landscape features of the area were used (Karkonosze). Such an early creation of these parks was influenced by the growing fashion for mountain hiking and the increased (thanks to the nearby health resorts) awareness of the benefits of contact with nature, while remaining in harmony with contemporary views on garden art.
\end{abstract}

Keywords: landscape gardens, public gardens, Silesia

\section{Preface}

This article is the first of three parts ${ }^{1}$ of a study which describes public greenery foundations that were created in the last quarter of the $18^{\text {th }}$ century on the outskirts of Jelenia Góra. Three surrounding hills were chosen for their location: Hausberg, Sättler and Galgenberg. The last two, in whole or in part, took on the names of these complexes: Helikon and Kavalierberg. For the inhabitants of Jelenia Góra, a densely built-up city, devoid of greenery and surrounded by medieval walls until the 1860s, they constituted places of rest, allowed contact with nature and provided extraordinary views of almost the entire Jelenia Góra Valley and the Karkonosze range with its highest hill - Śnieżka.

The formation of those complexes coincided with a revolutionary change in the way of shaping green areas, including gardens and parks. However, they have preceded many other public greenery layouts created in European cities or in their surroundings, including the oldest park in Wrocław called Szczytnicki. This park was founded in 1783, but as a private area; it became available to the public only in 1789. This fact makes Jelenia Góra an exceptional place, at the same time raising the question of what made the residents turn so early to nature and what made them create some of the projects carried out on those hills.

\section{Introduction}

In the last quarter of the $18^{\text {th }}$ century radical changes in the perception of gardens began to take place in Silesia. Consequently, those changes started to be visible also in the way gardens were shaped. Those vital changes were initiated by a modified attitude to nature. This attitude began changing in a large part of Europe in the eighteenth century (especially in the second part of the eighteenth century). Nature started to be seen as $a$ feeling organism organically connected with a human being ${ }^{2}$. A new approach to nature was originally represented only by private gardens. Public complexes began to appear on a wider scale only in the $19^{\text {th }}$ century. The two following articles will be published in the next issues of "The Folders of the Architecture, Urban Planning and Landscape Studies
Commission" and will include the presentations of separate gardens.

2 [Oosthoek, b.r.] 
It was also the time of the appearance of numerous publications devoted to the foundation of landscape gardens, starting with the work of T. Whateley from $1770^{3}$, through the work of H. Walpole and W. Mason ${ }^{4}$, H. Repton ${ }^{5}$ and many others. For the German language zone, the most important, especially in the early stage, was the five-volume work by C. C. L. Hirschfeld ${ }^{6}$, summarizing the state of knowledge on shaping the gardens and constituting the basic textbook for their creation in this area.

The gardens that were created at the time initially represented a sentimental trend, saturated with literary programs and rich symbolism based on philosophical and poetic ideas. They were included in numerous monuments and buildings (often of exotic forms), including greenhouses used for growing and displaying plants imported from all parts of the world. Around 1780, neoclassical tendencies became more popular in the landscape gardens. They were characterized by a greater restraint in the use of the architectural relic and by an increased interest in more spatial designs related to the surrounding landscape. Acting in accordance with the recommendations of the main theoretician of this trend, H. Repton (who introduced the term "landscaped garden"7), the natural properties of the area were first thoroughly explored, and then the gardens were shaped according to the character of the place. The natural valleys of rivers, hills, caves and springs were used to create beautiful views. They were diversified with single buildings, e.g. temples.

Another variation in the nature of landscape complexes was introduced by the Romanticism in the beginning of the $19^{\text {th }}$ century (although its elements were already present earlier, revealed in the cult of the Middle Ages, which was visible in England throughout the eighteenth century). At the same time, new aesthetic categories were applied to the gardens, including the picturesqueness defined as sudden variability, rawness and uniqueness.

It should be added here that in practice, especially outside the British Isles, these trends (sentimental and romantic) have often been combined within a single project, as exemplified by Seifersdorfer Tal park, created in 1781-1791 from the initiative and according to the concept of Christina von Brühl ${ }^{8}$. It was shaped using the Große Röder river, which was meandering northeast of Dresden and near the Seifersdorf castle. On both sides of the river a composition was created, stretching over a distance of one and a half kilometres. Numerous paths, connected by a lot of bridges, were laid along it. Among the trees artificial ruins and "temples" were erected, obelisks were set, and, above all, numerous monuments (some of them with subtitles and quotes) were placed ${ }^{9}$.

In the area of Seifersdorfer Tal, a wooden and bark-covered temple dedicated to Apollo and the Muses was erected, as the inscriptions on two sides of the preceding avenue informed ${ }^{10}$. This is an important thread because we will also find it in the area of Jelenia Góra in Helicon, which is discussed in more detail later in the study. Moreover, it is the closest to Silesia (though more modern) example of recalling the mythological scenery connected with Parnassus in a landscaped complex ${ }^{11}$.

Let us recall here that the earliest modern examples of such realizations associated with topos covering the mountain of Parnassus, Apollo and Muses were organized in the gardens of the $16^{\text {th }}$ century Italy, among others in the Florentine Giardino di Boboli, Villa Aldobrandini in Frascati, Giardino del Bufalo, at Pius IV Casino, on two grounds belonging to the d'Este family: in Tivoli and near Rome, in Villa Lante in Bagnaia, in Medicean gardens (Pratolino and near Rome) and also in Villa Barbaro near Maser ${ }^{12}$. Particular attention is drawn to Pratolino, where this group is almost the clou of the entire composition, pointing to its literary origin and theatrical

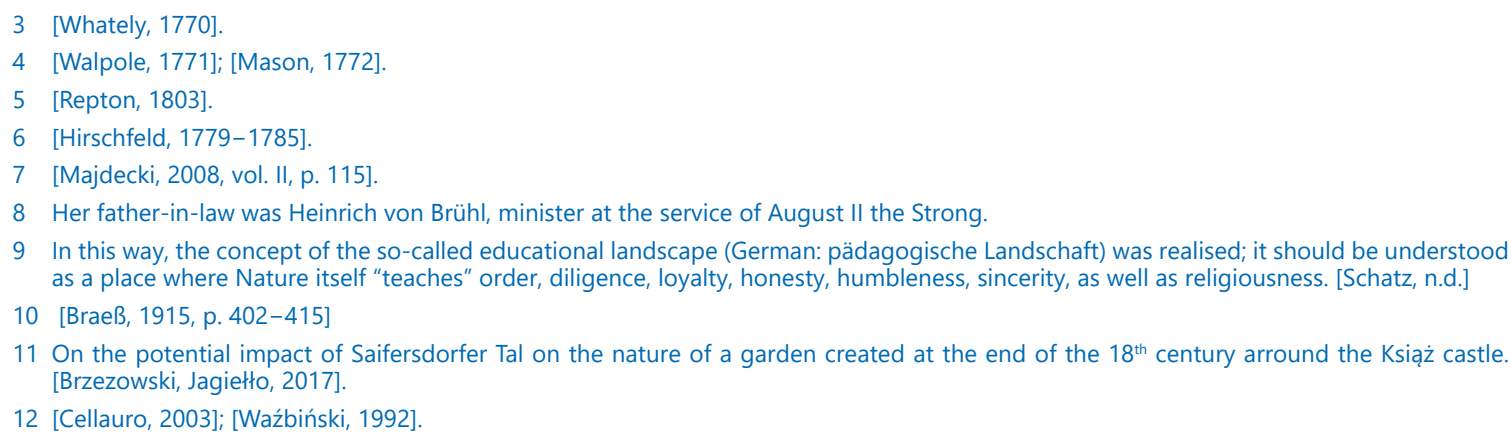


character and at the same time being an allusion to the virtues and genius of the Medici, reminding people of their sublime culture ${ }^{13}$.

This idea was taken outside of Italy by two German builders, engineers and garden designers at the same time, namely by Heinrich Schickhardt and Salomon de Caus. The latter, after returning from a trip to Italy, published in 1615 some drawings ${ }^{14}$ related to the topic. There is no proof, however, that any of these concepts have ever been implemented.

It was not until the second half of the seventeenth century that the hill of Parnassus was placed in the gardens of other European countries, first in the Netherlands, including Enghien and Catshuis (The Hague), and later in German complexes (Kleve, 1647; Salzdahlum, 1706-1709; Lützenberger Garten; Charlottenburg, 1702) ${ }^{15}$. In many places, the symbolic function of the Parnassus was combined with musical elements ${ }^{16}$ (this relationship is already known from Pratolino), which became part of the show played in the gardens.

Elevations, often artificially formed, called Parnassus, were given in the gardens of that time very diverse forms, character and context. It is shown by numerous engravings from the period. In each case, however, they were a visible influence of the Manneristic Italian art on the shape and iconographic program of Baroque gardens.

Let us add, at the end of these considerations, that the only Parnassus known to us, which was placed in the baroque garden in Silesia, was located in Piotrowice (Środa County). It was located on a small island and was given the shape of a conical mound crowned with a figure, probably of Apollo ${ }^{17}$.

In the Sefersdorfer Tal complex one should also pay attention to the monument dedicated to the author of a fundamental work for shaping gardens in the German territories from the third part of the eighteenth century - the "father of garden landscape art" , Christian Cay Lorenz Hirschfeld ${ }^{18}$. His work also summarizes the achievements of landscape theoreticians and practitioners, mainly English, and describes the state of knowledge at the time.

In the fourth volume of Hirschfeld's work a chapter can be found in which the properties of landscape gardens are described, depending on the topography of the place, namely the "garden in the valley" (Talgarten) and the "mountain garden" (Berggarten) ${ }^{19}$. The author drew the reader's attention to various types of valleys. He describes those in which "calmness", "seclusion", "gentleness", "gentle charm" and "harmony" dominate, but also others that are characterized by "severity", "boldness", "strength", "depth" and "violence." This corresponded to the concept of "sublime" introduced in the $18^{\text {th }}$ century to the garden aesthetics, which arose from the experience of the first walks in the Alps. Hirschfeld mentioned in his work also other non-natural elements that are part of such complexes, namely "Greek temples" and "Gothic castles" (preferably in picturesque remains), adding to them hermits, caves and other ruins (negatively referring to all exotic forms) ${ }^{20}$.

In the case of Jelenia Góra, though far away from the Alps, we deal with a deep valley of the meandering Bóbr River and with the accompanying Sättler range. On those hills Helicon was designed as one of the destinations for suburban walks. Helicon was a place inhabited by Muses and Apollo (next, on Parnassus). It was preceded from the city by the Hausberg hill. With time, more elements were added to this walking route, ending with a view of the high promontory on the Bóbr River valley, where the ruins of the medieval castle (Raubschloss) were located ${ }^{21}$.

It should be noted here that all the above-mentioned gardens, to which the theme of Parnassus, Helicon, Apollo and Muses was introduced, were private properties and accompanied private residences. In the Jelenia Góra Garden of Muses, on the other hand, we deal with a complex available to everyone. It is worth emphasizing, because - as already mentioned - the history of public complexes of greenery goes back to the beginning of the $19^{\text {th }}$ century (except for small squares in English cities, which were created as early as the $17^{\text {th }}$ century).

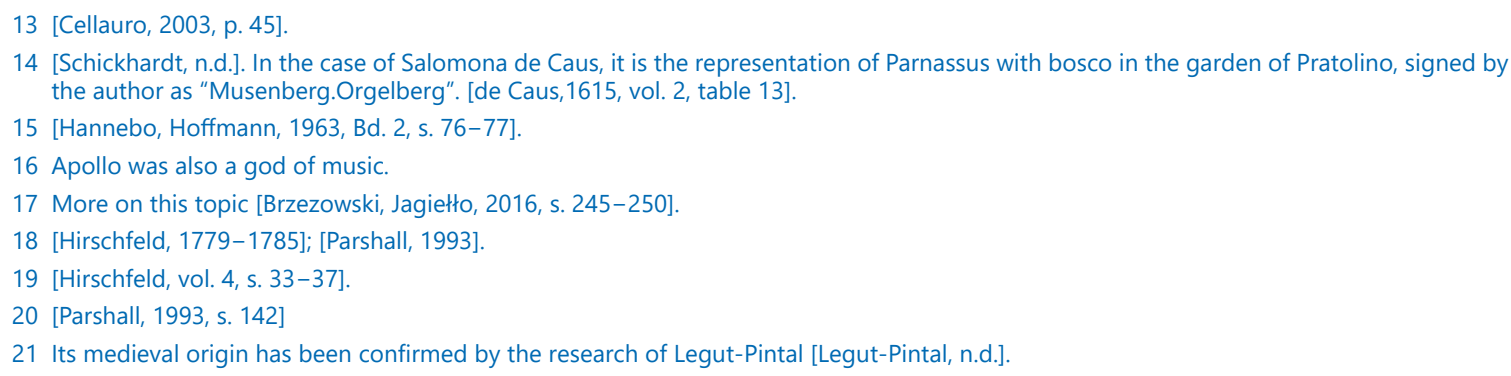


The most famous was the London Hyde Park. It was originally the royal property, but it was occasionally made available to the public from the $17^{\text {th }}$ century. It was permanently opened in the $19^{\text {th }}$ century, when urban parks were founded in London (the first one being Regent's Park, 1812). Much later, only after the regulation of Paris was carried out by Baron Haussmann in the years 1852-1891, such activities were undertaken in the French capital. Then, suburban forest areas were developed and the Bois de Boulogne and Vincennes forest were created. Together with other parks, among others Monceau and Montsouris, as well as newly built boulevards and squares, they have been connected by a combined urban greenery system ${ }^{22}$.

We, because of our country's location, will be most interested in Germany (or more precisely the Kingdom of Prussia). The first park intended for general use and equipped with various attractions was created (designed) the F.L. von Sckell, in 1789 in Munich (Englischer Garten). However, the oldest complex, considered to be the original of the so-called folk park, was created according to the design of P.J. Lenné only in 1823 in Magdeburg (Klosterberge-Garten).

In a later period, in the 1830s and 1840s, the first public greenery was established in the capital of Prussia Berlin (the transformation of the former Tiergarten, 1833-1839, the folk park - Friedrichshain, 1840-1846). The creation of the famous Flora Park in Cologne (1862) is also worth noting. It was established (like the extension of Tiergarten) according to the design of P.J. Lenné, active at that time also in the Jelenia Gora Valley ${ }^{23}$.

The end of the eighteenth century and the entire next century is also the time of transforming the areas previously connected with fortifications into a series of greenery called promenades or plants. Some of the oldest projects of this type are found in Mannheim and in Würzburg (1804). Soon afterwards, in the years 1813-1816, a promenade in Wrocław was established.

To sum up all that has been written above, activities aimed at creating places for recreation and entertainment in European cities, places which were generally accessible for the public, in the form of parks or developed suburban forest areas, generally started only in the $19^{\text {th }}$ century.

What, then, contributed to such an early, going back to the 70 s of the eighteenth century, effort to undertake the arrangement of suburban areas for the needs of the general population in the case of Jelenia Góra? Before we answer this question, let's look at this city, located in the centre of the Jelenia Góra Valley, connected with two rivers (the Bóbr and the Kamienna rivers) and surrounded by mountain ranges (Izerskie Mountains from the west, Kaczawskie Mountains from the north, Rudawy Janowickie from the east and from the south by the highest range of the Sudetes - Karkonosze) closer.

In the $17^{\text {th }}$ century, thanks to the economic situation on world markets, Jelenia Góra became one of the richest cities in Silesia. Linen fabrics produced here were exported to all European countries, to Russia and to the Americas. At that time, the city had a population of 6,000 residents living in 800 houses (including many suburban ones). The area of the proper city was surrounded by medieval walls and a dry moat. On the south and west side of the city, numerous summer houses of newly enriched and sometimes also newly ennobled merchants were built, surrounded by exquisite gardens. They were presented on the old plans and views of the city, among others on plans by F.B. Werner; they were also included in descriptions (sometimes even poetic) ${ }^{24}$. It can be said that while the possession of a magnificent tenement house in the city was a sign of prestige, a house outside the city with an impressive and exquisitely decorated garden symbolized luxury.

The prosperous development of the city was interrupted in 1742 when it became a part of the Prussian state. This led to the isolation of the city from the existing outlets. The problem was deepened by the change in the way the fabric was made due to the introduction of machines in its production. It made handicrafts, and this dominated in Jelenia Góra, unprofitable. The situation improved at the beginning of the $19^{\text {th }}$ century, when factories were built in suburban areas. Along with new jobs, there were also more residents, whose number increased from 6 thousand in 1800 to 15,6 thousand in 1885 .

The gardens in Jelenia Gora were also subject to significant changes. At the end of the $18^{\text {th }}$ century the Baroque complex of Daniel von Busch ${ }^{25}$ was mentioned among the most prominent ones. Yet, there was a

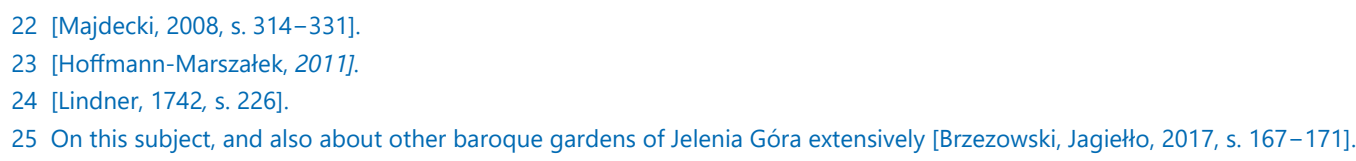


commentary added: The layout of the whole garden is old French but in more recent times, a lot of stiffness was subtracted from $i^{26}$, which shows that some "modernization" measures were taken there.

In this "stiffness subtraction", but on a much larger scale, Johann Christoph Schönau (1727-1802), the mayor of Jelenia Góra in the years 1780-1802, played an important role. He was the initiator of the founding and the founder of the most important park complexes in and around the city intended for its residents. The first complex used the advantage of the hill called Hausberg located on the north-eastern side of the city, in the bend of the Bóbr river. The second one was located on the Sättler hill behind Hausberg and was called Helicon. The third one was located south-east of the city and carried several names, the most popular being Cavalierberg. They served as places (visited by the inhabitants of Jelenia Góra even earlier) for walks, picnics and wandering. It is all the more important that until the 1860 s the city was stuck inside double defence walls. Outside the walls, in the northern section, in 1756-1763, a facility, unique in the Silesian area, was created in the place of a dry moat. It was 'an animal habitat', in which deer and roe deer were kept. Thus, the place was called Hirschgraben (now Jelenia Street). The remaining parts of the fortifications were dismantled only in the 1860 s. In its place, after 1865 , the city park was created in the form of a promenade.

The growing awareness of the beneficial effects resulting from direct contact with nature was also important. Due to those new tendencies spa complexes began to arise. They were created also in Silesia, including spa complexes near Jelenia Góra ${ }^{27}$. Local forest areas and attractive scenic spots were often included in their areas. Undoubtedly, impressive park layouts had a significant influence on changing the nature of gardens associated with Jelenia Góra and on arranging new greenery complexes in places that were considered attractive in their landscape and nature. Those parks were created, together with numerous residences, in the Jelenia Góra Valley in a way that opened them to the surroundings, including views of the Karkonosze range. The oldest of them (Ciszyca and Bukowiec) are dated to the last quarter of the eighteenth century. From the 1830s, an important role in shaping many of those parks played Peter Joseph Lenné, the general director of Prussian gardens ${ }^{28}$.

It is also impossible not to notice the influence of the growing popularity (from the middle of the $18^{\text {th }}$ century) of hiking in the Karkonosze Mountains. The geographical and natural values of the Jelenia Góra Valley influenced the birth and development of local tourism. Expeditions to Śnieżka, the highest peak of the Karkonosze Mountains, were organized as early as the middle of the $16^{\text {th }}$ century, and one of the first local tourists was Christoph Schilling, the rector of the Latin school in Jelenia Góra ${ }^{29}$. From the end of the $18^{\text {th }}$ century, the Jelenia Gora Valley became increasingly popular among wandering poets, painters and travellers looking for beautiful landscapes, inspiration and ideal destinations. There were among them, apart from many others, an eminent German poet of romanticism - Johann Wolfgang von Goethe ${ }^{30}$ and the famous naturalist and traveller - Alexander von Humboldt ${ }^{31}$. Also, the mayor Schönau, who was considered one of the precursors of Riesengebirgs-Verein ${ }^{32}$ in Jelenia Góra, was also involved in the promotion of tourism in the Karkonosze Mountains.

All this opened the inhabitants of Jelenia Góra very early to their closer and more distant surroundings, which were sometimes designed with surprising sophistication. These places encouraged people to go for walks and to take further trips, which were made for health, but also for intellectual and aesthetic experiences. Many of the inhabitants of Jelenia Góra at that time would probably sign under the following thought of Horace: Not everyone admires the same; for what one considers to be an uninhabited wilderness, the other, who feels like me, is going to call beauty ${ }^{33}$.

26 [Hensel, 1797, s. 655].

27 In the Jelenia Góra Valley it was Cieplice (known since the $12^{\text {th }}$ century, gaining popularity since the $17^{\text {th }}$ century), and closer to the Karkonosze - Swieradów Zdrój (from 1763)

28 On this topic [Hoffmann-Marszałek, 2011]

29 [Steć, Walczak, 1962].

$30 \mathrm{~J}$. W. von Goethe was in Cieplice in August 1790 [Scholz, 1887]

31 A. von Humboldt was in the Jelenia Góra Valley in June 1830 in connection with the visit of the Russian and Prussian court. He visited among others, Karpniki and Mysłakowice.[Hoffmann-Marszałek, 2011, s. 45].

32 [Donat, 2015]

33 Non eadem miramur; eo disconuenit inter/ meque et te; nam quae deserta et inhospita tesqua/ credis, amoena uocat mecum qui sentit. Horace, Letters, Book I, Letter XIV, verses 18-20. 


\section{The state of research}

Until now, the gardens of Jelenia Góra were not fully dealt with, although there is no shortage of source descriptions and studies based on them. They cover selected periods of the formation of those gardens ${ }^{34}$ or individual complexes, presented in the historical context. The transformation of Helikon Hill into a park layout, carried out at the end of the $18^{\text {th }}$ century, was presented in the "topographic-historical" description of Jelenia Góra from 1797 by Johann Daniel Hensel ${ }^{35}$. The same process was described in separate publications by anonymous authors, which appeared in 1790 and about $1796^{36}$, as well as (also by an unknown author) in an article published in 1790 in the "Schlesische Provinzial Blätter" 37 .

The Sättler hill was also very popular among researchers. The first one was Daniel Stoppe ${ }^{38}$, who in 1735 drew attention to the recreational qualities of this place. He also suggested a new name for this hill - Parnassus. It added some poetic values and symbolic referencesto the place. In Stoppe's book, we will also find the oldest graphic representation of the Sättler hill.

The earliest arrangement of Helicon on the Sättler hills was presented in an article that was a guide to the Jelenia Gora Valley published in $1785^{39}$. A year later, the publication of I. Krahn, discussing Helicon as well as the Elysian Fields, was published ${ }^{40}$. Helicon was also described by an anonymous author in a booklet published in $1796^{41}$. An almost identical description was written one year later by J.D. Hensel ${ }^{42}$. In both publications, there was also an area adjacent to Helicon, described as the Elysian Fields, with references to the $4^{\text {th }}$ Book of Aeneid by Virgil. Of special interest was the temple constructed on Helicon and dedicated to Frederick II. A separate article, published in the "Schlesische Provinzial Blätter"43, was devoted to this temple.

Historical research on presented complexes was made only in the 90 s of the twentieth century. Based on the above-mentioned sources, the history of the Hausberg hill is presented in the articles of R. Rzeszowski and I. Łaborewicz published in the "Rocznik Jeleniogórski" ${ }^{4}$. For our considerations the publication of the second of these authors, which contains a lot of information about the arrangement of this place, is particularly useful. The texts by Łaborewicz were also placed on information boards set a few years ago on the Kavalierberg hill. The complexes of Kavalierberg and Helicon have also been synthetically presented in the article by W. Brzezowski, describing the eighteenth-century gardens of Jelenia Góra ${ }^{45}$. A monographic publication was also devoted to the monument of the mayor Schönau, the founder of the Kavalierberg and Helicon hills ${ }^{46}$.

An important contribution to the restoration of the importance of the former Helicon is also done by a Jelenia Góra researcher Eugeniusz Gronostaj, who provides information on Helicon on various internet forums, where he places richly illustrated studies ${ }^{47}$. He has also published an article about Helicon in "Rocznik Jeleniogórski"48. His actions have vastly contributed to the continual restoration of the readability of the composition of this complex. It has been achieved through corrections in the trees planting, the improvement in the trails system and the placement of information boards.

In the study of ancient landscape gardens of Jelenia Góra a large number of iconographic materials play a very important role. These include drawings, maps, postcards and photographs. They will be presented in more detail in the subsequent parts of this study.

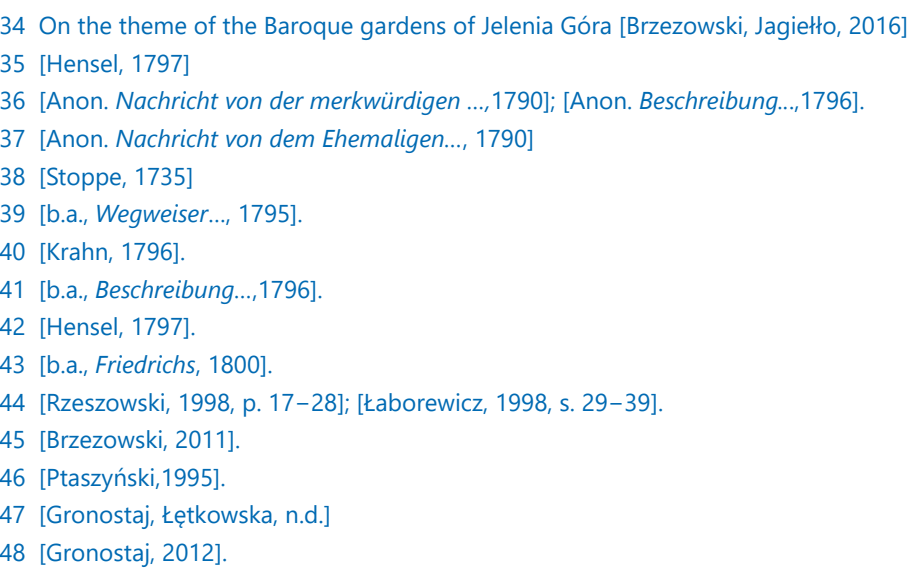


Despite the apparent abundance of sources and studies devoted to the complexes of Hausberg, Helicon and Kavalierberg, it should be emphasized that they focus almost exclusively on the historical-topographic description of "things". The authors of this article (and its other two parts) believe that this does not cover the whole topic, and thus share the opinion expressed by a renowned expert of gardens J.D. Hunt: Gardens generally deserve to be studied at the intersection between physical place and metaphysical idea. This is only in part a reworking of the old formula about form and function; a garden's function may not only involve the growing of food, social uses, political prestige and power; we must study how the physical facts of a garden intersect with a whole gamut of less tangible but no less instrumental concerns ${ }^{49}$.

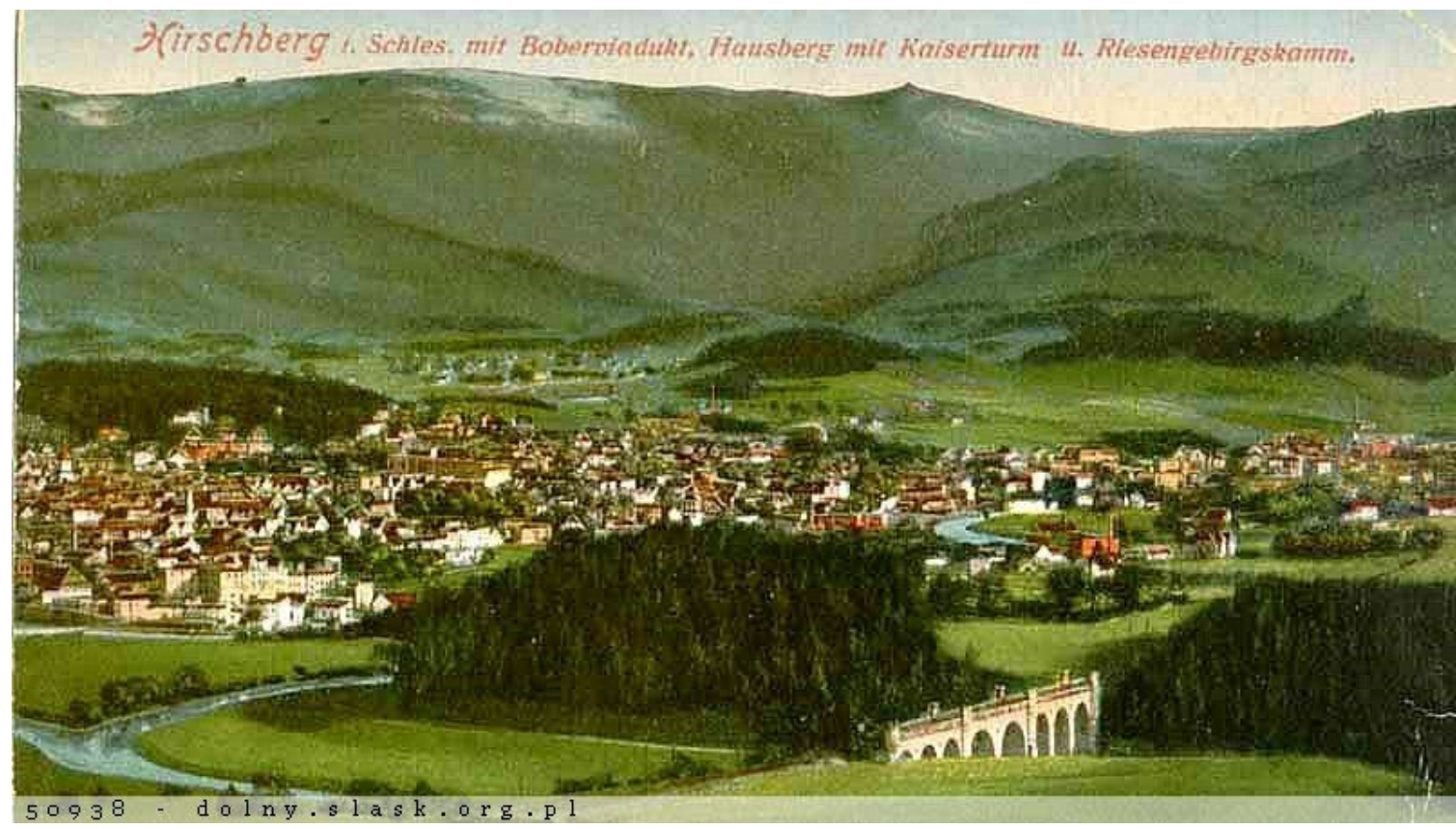

Fig. 1. Jelenia Góra, in the background the Giant Mountains, in the foreground the Hausberg hill. Postcard from the beginning of the XX century, (https://polska-org.pl/632930,foto.html [access date: 12.10.2018].

\section{Bibliography}

[1] [no autor],1790. Nachricht von der merkwürdigen Umsachaffung des ehemaligen Galgenberges bei Hirschberg in einen schönen Volksgarten. Schmiedeberg.

[2] [no autor], 1790. Nachricht von dem Ehemaligen Galgenberge bey Hirschberg: Schlesische Provinzial Blätter, 11, $346-357$.

[3] [no autor], 1795. Wegweiser durch das Riesengebirge, w: Berlinischer Almanach zum Vergnügung und zur Verbreitung nützlicher Kenntniße für 1796. Berlin,1-63.

[4] [no autor],1796. Beschreibung des Pflanzberges, Helikons und denen Elisäischen Feldern bei Hirschberg, (no place of issue)

[5] [no autor] 1800. Friedrichs des Einzigen Denkmal auf dem Hirschberger Helikon, "Schlesische Provinzial Blätter", 31 , $311-325$.

[6] Braeß M., 1915. Das Seifersdorfer Tal mit seinen Denkmälern: Mitteilungen des Landesvereins

[7] Caus S. de, 1615. Les Raisons des forces mouvantes, Francfort, vol. 2.

[8] Brzezowski W., 2011.Ordnung, Fleiß, Natur und Kunst... The Gardens of Jelenia Góra in the 18 ${ }^{\text {th }}$ century: Stadtfluchten/ Ucieczki z miasta (Escapes from the city), edited by M. Omilanowska, B. Störtkuhl, Warszawa, 67-76.

[9] Brzezowski W., Jagiełło M., 2016. Ogrody na Ślasku. T. 2. Barok (Gardens in Silesia. Vol. II. The Baroque), Wrocław.

[10] Brzezowski W., Jagiełło M., Założenie ogrodowo-krajobrazowe w Książu: Książ. Pamiętajmy o ogrodach (Landscape garden in Książ: Książ. Let's remember the gardens, edited by B. Lejman, Wrocław 2017, s. 37-64. 
[11] Cellauro L., 2003. Iconographical aspects of the Renaissance villa and garden: Mount Parnassus, Pegasus and the Muses: Studies in the History of Gardens \& Designed Landscape, vol. 21, 42-56.

[12] Donat T., Stadtdirector Schönau, ein Vorläufer des Riesengebirgs-Vereins, (transcription Ulrich Junker, Bodnegg 2015). http://jbc.jelenia-gora.pl/Content/18463/JEL_19122_2015_Stadtdirector-Schona_19122_Sch\%C4\%82\%C2\%B6nau_Wanderer_1882.pdf [access date: 27.10.2018];

[13] Gronostaj E., Łętkowska A., b.r. Bogactwo przyrodniczo-historyczne Borowego Jaru w rozwoju turystyki i aktywnego wypoczynku. ( The richness of nature and history of Borowy Ravine in the development of tourism and active recreation) http://wpt.kpswjg.pl/public/ckfinder/userfiles/files/borowy_jar_walory_15_09_17 [access date: 24.10.2018]

[14] Gronostaj E., 2012. Parnas na Siodle. Helikon - siedziba muz (Parnas on the Saddle. Helikon - the seat of Muses): Rocznik Jeleniogórski, 261-270.

[15] Hannebo D., Hoffmann A., 1963. Geschichte der deutschen Gartenkunst in drei Bänden. Hamburg, vol. 2.

[16] Hensel J. D., 1797. Historisch-topographische Beschreibung der Stadt Hirschberg in Schlesien. Hirschberg.

[17] Hirschfeld Ch. C. L. 1779-1785, Theorie der Gartenkunst, vol. 1-5, Leipzig.

[18] Hoffmann-Marszałek A., 2011. Działalność Petera Josepha Lennégo oraz innych projektantów ogrodów na terenie Kotliny Jeleniogórskiej w XIX w. (Activities of Peter Joseph Lenné and other garden designers in the Jelenia Góra Valley in the $19^{\text {th }}$ century) (Mysłakowice, Wojanów, Łomnica i Karpniki). pr dr. wykonana na WA PWr. (Activity of Peter Joseph Lenné and other garden designers in the Jelenia Góra Valley in the $19^{\text {th }}$ century) PhD thesis executed on Faculty of Architecture, Wrocław University of Science and Technology

[19] Horacy, Listy, Księga I, List XIV, wersy 18-20. Horace, Letters, Book I, Letter XIV, verses 18-20

[20] Hunt J. D., 1996. The Italian Garden: Art., Design and Culture, Cambridge.

[21] Krahn I., 1796, Vom Helikon und den Eisäischen Feldern bei Hirschberg, Hirschberg.

[22] Legut-Pintal M., A study of the defensiv system of Jelenia Góra: http://wratislavia.archeo.uni.wroc.pl/18-tom/16.pdf [data dostępu: 2.10.2018]

[23] Lindner K.G., 1742 . Historische und poetische Beschreibung des Landberühmten Hausberges oder Burglehns beÿ Hirschberg aus alten und sichren schriftlichen Urkunden gesammlet. Hirschberg.

[24] Łaborewicz I., 1998. Historia Wzgórza Bolesława Krzywoustego (Hausberg) w Jeleniej Górze od połowy XV w. do dnia dzisiejszego (History of the Bolesław Krzywousty Hill (Hausberg) in Jelenia Góra from the mid-15 ${ }^{\text {th }}$ century to the present day): Rocznik Jeleniogórski, p. 29-39.

[25] Majdecki L., 2008. Historia ogrodów (Garden history). Warszawa, t. II.

[26] Mason M., 1772. The English Garden. London.

[27] Oosthoek J., Romantisism and nature: https://www.eh-resources.org/romanticism-and-nature/ [data dostępu access date: 25.10.2018]

[28] Parshall L., 1993. C. C. L. Hirschfeld's concept of the garden in the German Enlightenment: The Journal of Garden History, vol. 13, p. 127-171.

[29] Ptaszyński J., 1995. Johann Christoph Schönau i jego pomnik (Johann Christoph Schönau and his monument): Karkonosze, 1, p. 8-9.

[30] Repton H., 1803.Observations on the Theory and Practice of Landscape Gardening. London.

[31] Rzeszowski R., 1998. Legendarne dzieje i historia Wzgórza Krzywoustego i okolic do połowy XV wieku (Legendary past and history of Krzywousty Hill and the surrounding area until the middle of the 15 $5^{\text {th }}$ century): "Rocznik Jeleniogórski," p. 17-28.

[32] Sächsischer Heimatschutz, 4 (1915) 10, Dresden, p. 402-415.

[33] Schatz Ch., Brühl, Johanne Margarethe Christina (Jeanne Marguerite Christine, gen. Tina) Gräfin von: Sächsische Biografie, Institut für Sächsische Geschichte und Volkskunde e.V., (red.) Martina Schattkowsky. http://saebi.isgv.de/biografie/ Christina_von_Br\%C3\%BChl_(1756-1816) [access date: 18.12.2017]

[34] Schickhardt H., Beschreibung einer Reiss..., Württembergische Landesbibliothek Stuttgart, Inv. No Cod. hist. fol. 562, p. 193v.

[35] Scholz [P.], 1887. Goethes Riesengebirgsreise im Jahre 1790: Wanderer im Riesengebirge, Hirschberg, nr 7, 84-89.

[36] Steć T., Walczak W., 1962. Karkonosze. Monografia krajoznawcza (Karkonosze. Tourist monography), Warszawa.

[37] Stoppe D., 1735, Der Parnaß im Sättler oder Scherz- und Ernsthafte Gedichte Herrn Daniel Stoppens. Frankfurt/Leipzig.

[38] Walpole H., 1771. Essay on modern Gardening. Strawbery Hill.

[39] Waźbiński Z., 1992. Willa Medycejska w Pratolino uratowana... (Villa Medici in Pratolino rescued): „Ochrona zabytków”, vol. 45, nr 1-2, 65-70.

[40] Whately T., 1770. Observations on Modern Gardening, illustrated by descriptions. London. 


\section{Najwcześniejsze publiczne założenia zieleni związane z Jelenią Górą, cz. 1.}

Streszczenie: W trzeciej tercji XVIII w. zaczęły powstawać na ówczesnych terenach podmiejskich Jeleniej Góry, najwcześniejsze na terenie Śląska publiczne ogrody krajobrazowe przeznaczone dla wszystkich mieszkańców. Przy ich zakładaniu wykorzystano naturalne walory krajobrazowe okolicy (Karkonosze). Na wczesne powstanie tych założeń wpływ miała budząca się moda na górskie wędrówki oraz rosnąca (dzięki pobliskim uzdrowiskom) świadomość pożytków płynących z kontaktu z naturą, pozostająca w zgodzie z ówczesnymi poglądami na sztukę ogrodową.

Słowa kluczowe: ogrody krajobrazowe, ogrody publiczne, Śląsk 